Received March 22; revised May 18, 1972.

1 Hecht, M. K., System. Zool., 12, 20 (1963).

2 Estes, R., Amer. Zool., 5, 319 (1965).

3 Dorf, E., Contr. Mus. Paleont. Univ. Michigan, 8, 181 (1959).

4 Brunner, G., Neues Jb. Min. Geol. Paläont. Abh., 100, 83 (1954).

5 Marcus, H., Rev. Agricult. Bolivia, 2, 29 (1945).

6 Taylor, E. H., The Caecilians of the World, 38 (Univ. Kansas Press, Lawrence, Kansas, 1968).

7 Wake, M. H., Copeia, No. 1, 216 (1969).

${ }^{8}$ Kuhn, O., Die Amphibien, 42 (Verlag Oeben, Krailling bei München, 1965).

9 Paula Couto, C. de, Notas Prelim. Est. Div. Geol. Min. Brasil, No. 49, 1 (1949).

10 Price, L. I., and Paula Couto, C. de, Anais $2^{\circ}$ Congr. Panamer. Eng. Min. Geol., 3, 149 (1946).

11 Paula Couto, C. de, Notas Prelim. Est. Div. Geol. Min. Brasil, No. 75, 1 (1953).

12 Paula Couto, C. de, Bull. Amer. Mus. Nat. Hist., 99, 359 (1952).

13 Paulo Couto, C. de, Rev. Mus. Argent. Cienc. Natr., 8, 135 (1962).

14 Fox, P., Heezen, B., and Johnson, G., Science, 170, 1402 (1970).

\section{Culture of Cells from the Urine of Newborn Children}

THE increasing importance of amniocentesis for the diagnosis of disease in utero has focused attention on the cells obtained by this procedure. Culture of amniotic fluid cells is becoming an established procedure for the identification of foetuses with chromosomal and metabolic abnormalities. Cytogenetic and biochemical studies of these cells in culture and morphological studies of the uncultured cells have shown that they are of
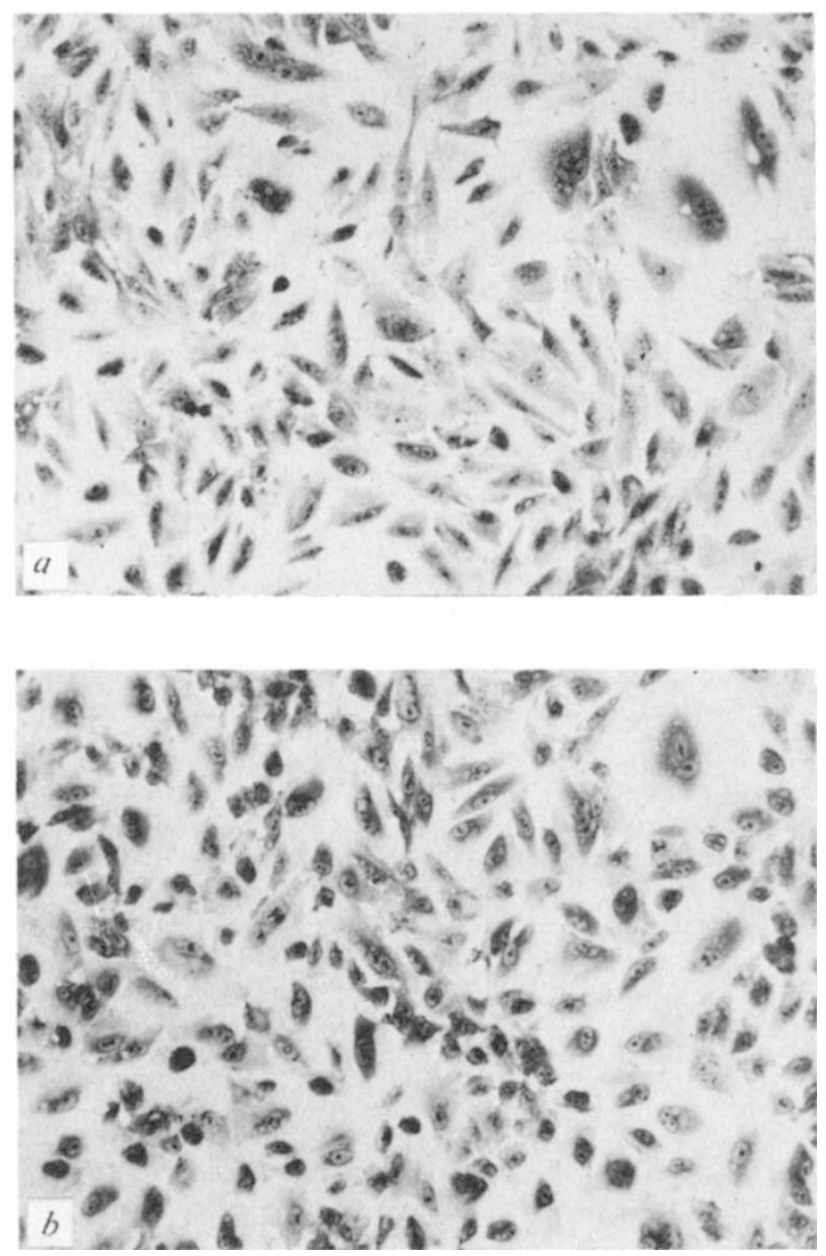

Fig. 1 Cells cultured from (a) urine and (b) amniotic fluid as seen $24 \mathrm{~h}$ after the third subculture (stain toluidine blue, $\times 100$ ). foetal origin ${ }^{1-3}$. However, the exact origin of the cells which grow remains speculative and several possibilities have been suggested including exfoliated cells from the amnion or from foetal $\operatorname{skin}^{2,3}$ and also from the foetal respiratory ${ }^{4}$ and urogenital ${ }^{3,4}$ tracts. Since foetal urine undoubtedly contributes to the amniotic fluid as gestation progresses ${ }^{5}$ it seemed reasonable to assume that some of the cells cultured from amniotic fluid could be derived from the foetal urinary tract.

Samples of urine were collected in sterile bags from four infants less than two days old. For tissue culture, the urine samples were then treated as amniotic fluids; they were centrifuged at 1,000 r.p.m. for $10 \mathrm{~min}$, the supernatant decanted, the cells resuspended in tissue culture medium and then transferred to Petri dishes containing cover slips. Ham's F10 TCM containing streptomycin and penicillin with the addition of $30 \%$ foetal calf serum was used. Cultures were incubated at $37^{\circ} \mathrm{C}$ in an atmosphere of $5 \% \mathrm{CO}_{2}$ in air. Although one culture showed contamination within $24 \mathrm{~h}$, the remaining three were successfully maintained and proliferating cells were first observed at 6, 9 and 10 days respectively. Sufficient cells were present to allow harvesting for chromosome studies at 12 days in the first case and at $\mathbf{1 7}$ days for the other two. These culture times are similar to those being obtained at the present time in this laboratory for amniotic fluid cell cultures.

Using light microscopy the cultured urine cells appear morphologically similar to those cultured from amniotic fluid (Fig. 1); but further characterization of these two types of cell strain is required. Cell cultures have now been set up using urines from a total of eight infants aged less than 2 days and of gestational ages ranging from 31 to 40 weeks. Seven of these cultures have produced primary cell strains, one of which has now reached the seventh pass. A small number of cultures from older children have failed to grow. The only previous attempt to culture cells from urine is that of Jacobson and Barter $^{4}$ who set up cultures from sheep urines and bladder aspirates from four human foetuses; however, only one of the former was successful.

The culture of cells from neonatal urine, embodying simplicity in collection and in culture technique, could provide a non-traumatizing procedure for cytogenetic investigations when studies on tissue other than blood are required. Moreover, the most potentially useful application of this technique may be the production of primary cell strains for use in the investigation of inborn errors of metabolism at a biochemical and molecular level.

We thank Dr F. Cockburn for collecting the urine samples. Grant R. Sutherland A. Douglas Bain

Department of Pathology, Royal Hospital for Sick Children, and the University of Edinburgh

1 Van Leeuwen, L., Jacoby, H., and Charles, D., Acta Cytol., 9, 442 (1965).

2 Votta, R. A., de Gagneten, C. B., Parada, O., and Giulietti, M. Amer.J. Obstet. Gynec., 102, 571 (1968).

3 Wachtel, E., Gordon, H., and Olsen, E., J. Obstet. Gynaec. Br. Commonw., 76, 596 (1969).

4 Jacobson, C. B., and Barter, R. H., Amer. J. Obstet. Gynec., 99, $796(1967)$.

5 Emery A. E. H. in Modern Trends in Human Genetics-1 (edit. by Emery, A. E. H.), 268 (Butterworths, London, 1970).

\section{Effect of Sodium Nitrilotriacetate on Toxicity, Teratogenicity, and Tissue Distribution of Cadmium}

MAJOR US detergent manufacturers voluntarily agreed in 1970 to discontinue the use and manufacture of trisodium nitrilotriacetate (NTA), pending further toxicological studies. 